\title{
ANALISIS PENDETEKSIAN FINANCIAL STATEMENT FRAUD DENGAN PENDEKATAN MODEL BENEISH PADA PERUSAHAAN BUMN
}

\author{
Hantono $^{1}$ \\ ${ }^{1}$ Program Studi Akuntansi, Universitas Prima Indonesia, Jalan Belanga No.1 Simp.Ayahanda Medan, Sumatera \\ Utara, 20118, Indonesia \\ E-mail: hantono_78@yahoo.com
}

\begin{abstract}
This study aims to detect the possibility of fraud on BUMN companies listing on the Indonesia Stock Exchange 2012-2016 by using eight of Beneish's Model.The object of this study is all BUMN companies listing on the Indonesia Stock Exchange which publishes audited financial statements for fiscal year 2012 - 2016, which amounted to 20 (twenty) companies. The sampling technique is by using purposive sampling method where the sample is determined based on certain criteria determined by the researcher and has limitations in terms of generalization. The sample of research is 50 (fifty companies) Data collection method using documentation method Data analysis technique used is descriptive quantitative analysis using Beneish Ratio Index Variable in this research is Days' Sales In Receivables Index (DSRI), Gross Margin Index ( GMI), Asset Quality Index (AQI), Sales Growth Index (SGI), and Total Accruals To Total Assets Index (TATA)) Based on the eight models of Beneish's Model, the Days' Sales In Receivables Index (DSRI), Gross Margin Index GMI), Asset Quality Index (AQI), Sales Growth Index (SGI), and Total Accruals To Total Assets Index (TATA) have no effect on fraud.
\end{abstract}

Keywords: financial statement, fraud, Beneish's Model

\section{PENDAHULUAN}

Setiap perusahaan mempunyai laporan keuangan yang bertujuan untuk menyediakan informasi yang menyangkut posisi keuangan, kinerja serta perubahan posisi keuangan suatu perusahaan yang bermanfaat bagi pemakai laporan keuangan dalam pengambilan keputusan Laporan keuangan harus disiapkan secara periodik untuk pihak-pihak yang berkepentingan dan memberikan informasi keuangan suatu perusahaan yang dapat digunakan untuk mengambil keputusan dan juga menunjukkan kinerja yang telah dilakukan oleh pihak manajemen (stewardship) atau pertanggungjawaban manajemen.

Kasus fraud yang baru-baru ini terjadi ialah kasus yang menimpa perusahaan Toshiba. Skandal akuntansi berkaitan dengan financial statement fraud. Perusahaan tersebut diduga melakukan penggelembungan keuntungan perusahaan. Komite independen mengungkapkan bahwa kondisi keuangan perusahaan elektronika dan teknologi energi nuklir asal Jepang tersebut berbeda dengan hasil temuan komite independen. Kondisi keuangan Toshiba diduga menyimpang karena terjadi penggelembungan laba hingga US\$ 1,2 miliar selama tujuh tahun. Hal tersebut terjadi pada periode antara April 2008 hingga Maret 2014. Kasus tersebut terungkap sejak April 2015 dan semakin memburuk pada Mei 2015 setelah komite independen mengambil alih evaluasi laporan keuangan, hal ini menyebabkan turunya saham Toshiba sekitar 20\% (Liputan6.com, 2015).

PT.Kereta Api Indonesia (PT KAI) diduga menyajikan laporan keuangan yang tidak sesuai dengan standar akuntansi dan ketentuan berlaku sehingga dapat memberikan informasi asimetri bagi para pihak berkepentingan dalam melakukan pengambilan keputusan. Kasus ini juga berkaitan dengan masalah pelanggaran kode etik profesi akuntansi. Diduga terjadi 
rekayasa informasi dalam laporan keuangan PT KAI tahun 2005 sehingga BUMN tersebut dicatat meraih keutungan sebesar $\mathrm{Rp}$ 6,9 Miliar walaupun terdapat kecenderungan perusahaan mengalami rugi sebesar Rp 63 Miliar (Harian Kompas, tanggal 29 Mei 2014).

Kecurangan dalam laporan keuangan dapat dilakukan dengan cara melakukan penghilangan pencatatan secara sengaja untuk mengelabui para pengguna. Fraud merupakan perlakuan melanggar hukum yang bermaksud untuk memperoleh keuntungan pribadi dan kelompok sehingga merugikan pihak lain (Priantara, 2013:4). Hariri et al.(2013) melakukan penelitian mengenai kecurangan laporan keuangan menggunakan Beneish M-Score pada PT XYZ, hasil penelitiannya menyatakan bahwa secara keseluruhan Beniesh M-Score PT XYZ mencapai angka -3,94 pada tahun 2010, 0,70 di tahun 2011, -3,32 pada tahun 2012 dan -2,38 pada tahun 2013. Hasil tersebut menunjukkan adanya indikasi bahwa PT XYZ melakukan praktik manipulasi terhadap laporan keuangan yang dilakukan secara terus menerus pada tahun 2010-2013.

Hermansyah (2015) menyatakan bahwa model Beneish M-score merupakan metode untuk mengungkapkan adanya kemungkinan perusahaan melakukan fraud terhadap pendapatan yang dicatat dalam laporan keuangan. Christy,et.al. (2015), menyatakan bahwa penganalisaan atau penilaian terhadap posisi keadaan keuangan dan perkembangannya pada suatu perusahaan dapat dilakukan oleh dua pihak, yaitu pihak yang ada dalam perusahaan (internal) dan pihak di luar perusahaan(eksternal). Kemungkinan adanya laporan keuangan yang tidak asli atau adanya praktik kecurangan karena sudah diolah sedemikian rupa sehingga kelihatan baik.

Darmawan (2016) menyatakan bahwa pada perusahaan manufaktur yang terdaftar di BEI tahun 2013-2014 terdapat 4,6\% perusahaan manufaktur tergolong manipulator, 64,8\% perusahaan manufaktur tergolong non manipulator, dan $30,7 \%$ perusahaan manufaktur tidak tergolong manipulator maupun non manipulator. Penelitian ini bertujuan untuk menganalisis fraud atas laporan keuangan dengan menggunakan model M-Score. Penelitian ini diharapkan dapat menambah literatur di bidang ilmu pengetahuan etika profesi akuntansi dan audit dengan pendekatan delapan model Beneish M-Score.

\section{TINJAUAN PUSTAKA}

\subsection{Laporan Keuangan}

Pada awalnya laporan keuangan bagi suatu perusahaan hanyalah berfungsi sebagai "alat pengujian" dari pekerjaan fungsi bagian pembukuan, akan tetapi untuk selanjutnya seiring dengan perkembangan zaman, fungsi laporan keuangan sebagai dasar untuk dapat menentukan atau melakukan penilaian atas posisi keuangan perusahaan tersebut. Dengan menggunakan hasil analisis tersebut, maka pihak-pihak yang berkepentingan dapat mengambil suatu keputusan. Menurut Fahmi (2012:21),laporan keuangan merupakan suatu informasi yang menggambarkan kondisi laporan keuangan suatu perusahaan dan lebih jauh informasi tersebut dapat dijadikan sebagai gambaran kinerja keuangan perusahaan tersebut.

Menurut PSAK No. 1 Tahun 2015, Laporan Keuangan adalah penyajian terstruktur dari posisi keuangan dan kinerja keuangan suatu entitas. Laporan ini menampilkan sejarah entitas yang dikuantifikasi dalam nilai moneter. Laporan keuangan merupakan bagian dari proses pelaporan keuangan. Laporan keuangan yang lengkap biasanya meliputi neraca, laporan laba rugi, laporan perubahan posisi keuangan (yang dapat disajikan dalam berbagai cara misalnya, sebagai laporan arus kas, atau laporan arus dana), catatan dan laporan lain serta materi penjelasan yang merupakan bagian integral dari laporan keuangan. Disamping itu juga termasuk skedul dan informasi tambahan yang berkaitan dengan laporan tersebut, misalnya, informasi keuangan segmen industri dan geografis serta pengungkapan pengaruh perubahan harga. Menurut Kasmir (2016:7), laporan keuangan adalah laporan yang menunjukkan kondisi keuangan perusahaan pada saat ini atau dalam suatu periode tertentu. 
Melalui laporan keuangan juga akan dapat dinilai kemampuan perusahaan untuk memenuhi seluruh kewajiban-kewajibannya baik jangka pendek maupun jangka panjang, struktur modal perusahaan, pendistribusian pada aktivanya, efektivitas dari penggunaan aktiva, pendapatan atau hasil usaha yang telah dicapai, beban-beban tetap yang harus dibayarkan oleh perusahaan serta nilai-nilai buku dari setiap lembar saham perusahaan yang bersangkutan.

\subsection{Fraud}

Fraud merupakan suatu kondisi yang mungkin akan ditemukan oleh auditor dalam suatu audit. Auditor mungkin akan menemui berbagai temuan dan bentuk yang terjadi di lapangan. Bukan hanya itu mungkin auditor juga akan melihat berbagai cara yang dilakukan oleh pelaku dalam melakukan fraud serta siapa saja pelaku yang memungkinkan untuk melakukan fraud.

Statement of Auditing Standards No. 99 (SAS No. 99) mengenai Consideration of Fraud in a Financial Statement Audit pada Oktober 2002. Tujuan dikeluarkannya SAS No.99 adalah untuk meningkatkan efektivitas auditor dalam mendeteksi kecurangan dengan menilai pada faktor risiko kecurangan perusahaan. Faktor risiko kecurangan yang diadopsi dalam SAS No. 99 didasarkan pada teori faktor kecurangan Cressey (1953) yang dikenal dengan konsep fraud triangle atau segitiga kecurangan.

Fraud atau yang sering dikenal dengan istilah kecurangan merupakan hal yang sekarang banyak dibicarakan di Indonesia. Pengertian fraud itu sendiri merupakan penipuan yang sengaja dilakukan sehingga dapat menimbulkan kerugian pihak lain dan memberikan keuntungan bagi pelaku kecurangan dan atau kelompoknya (Sukanto, 2009). Fraud adalah tindakan bersifat umum dan mencakup beragam makna berupa cara cerdik seseorang yang dirancang untuk mendapatkan keuntungan dengan penyajian yang salah (Albrecht et al.,2011).

Menurut Priantara (2013:90), perbuatan fraud yang dilakukan manajemen berupa:

a. Manipulasi, pemalsuan, atau pengubahan terhadap catatan akuntansi atau dokumen pendukung yang merupakan sumber penyajian laporan keuangan.

b. Kesengajaan dalam penyajian atau sengaja menghilangkan (intentional omissions) suatu transaksi, kejadian, atau informasi penting dari laporan keuangan.

c. Salah penerapan secara sengaja mengenai prinsip akuntansi (jumlah, klasifikasi, penyajian, pengungkapan).

\subsection{Beneish M-score}

Untuk mengkategorikan perusahaan terindikasi adanya manipulasi (fraud) atau tidak diperlukan sebuah model perhitungan yang membantu untuk mendeteksi pergerakan tidak wajar pada laporan keuangan, yakni Beneish M-Score Model (Beneish, 2012). Model ini menggunakan 8 variabel berupa rasio perhitungan keuangan untuk mengidentifikasikan apakah perusahaan memiliki indikasi untuk memanipulasi pendapatan dalam laporan keuangan. Variabel dalam model didasarkan pada perubahan tahun ke tahun, hal ini memberikan tanda adanya masalah potensial ketika penyebut kecil.

Delapan variabel yang digunakan dalam Beneish M-Score Model:

a. $\quad$ Days Sales in Receivable Index (DSRI)

Variabel Days Sales in Receivable Index adalah rasio penjualan harian dalam piutang pada tahun pertama dimana manipulasi laba ditemukan (tahun t) dengan ukuran yang sesuai pada tahun $\mathrm{t}_{-1}$. Days Sales in Receivable Index untuk mengukur apakah piutang dan pendapatan sudah berada pada keseimbangan antara dua tahun berturut-turut. Jumlah yang besar dalam days sales in receivables dapat berarti akibat dari perubahan kebijakan kredit untuk memacu penjualan dalam menghadapi persaingan yang meningkat, tetapi peningkatan yang tidak proporsional dalam piutang juga dapat dipengaruhi oleh inflasi. 
Rumus Days Sales in Receivables Index (DSRI) adalah sebagai berikut:

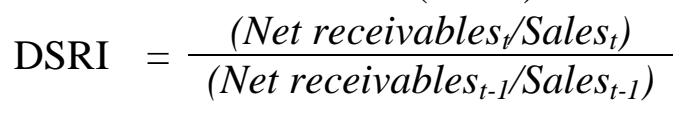

b. Gross Margin Index (GMI)

Gross Margin Index merupakan rasio marjin laba kotor pada tahun sebelum (t-1) ke margin laba pada tahun berjalan (t). Jika Gross Margin Index lebih besar dari 1 yang berarti mengindikasikan sinyal yang negatif bagi prospek perusahaan (Lev dan Thiagarajan, 1993). Jika perusahaan memiliki prospek negatif, maka perusahaan lebih rentan untuk memanipulasi laba.

Rumus Gross Margin Index (GMI) adalah sebagai berikut :

c. Asset Quality Index (AQI)

$$
\mathrm{GMI}=\frac{\left(\left(\text { Sales }_{\mathrm{t}-1}-\text { COGS }_{\mathrm{t}-1}\right) / \text { Sales }_{\mathrm{t}-1}\right)}{\left(\left(\text { Sales }_{\mathrm{t}}-\mathrm{COGS}_{\mathrm{t}}\right) / \text { Sales }_{\mathrm{t}}\right)}
$$

Asset Quality Index untuk membandingkan aktiva tidak lancar yang dimiliki oleh perusahaan selain aktiva tetap dengan total aktiva perusahaan pada suatu tahun (t) dan tahun sebelumnya ( $\mathrm{t}-1$ ). Rumus Asset Quality Index (AQI) adalah sebagai berikut :

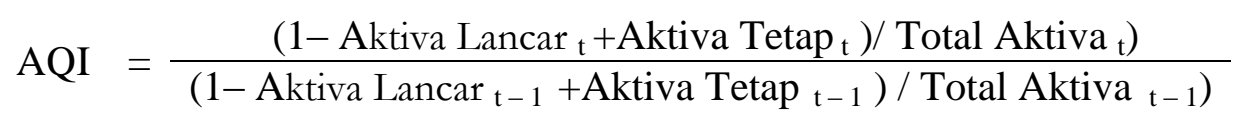

d. $\quad$ Sales Growth Index (SGI)

Sales Growth Index untuk mengukur tingkat pertumbuhan penjualan perusahaan. Hasil yang lebih besar dari 1 mengindikasikan bahwa penjualan meningkat dari tahun sebelumnya. Sales Growth Index bukanlah merupakan indikasi manipulasi pendapatan, tetapi perusahaan yang mengalami pertumbuhan penjualan lebih cenderung untuk melakukan manipulasi pendapatan.

Rumus Sales Growth Index (SGI) adalah sebagai berikut :

$$
\text { SGI }=\text { Penjualan }_{(\mathrm{t})} / \text { Penjualan }_{(\mathrm{t}-1)}
$$

e. Depreciation Index (DEPI)

Depreciation Index untuk membandingkan beban depresiasi terhadap aktiva tetap sebelum depresiasi pada suatu tahun $(\mathrm{t})$ dan tahun sebelumnya $(\mathrm{t}-1)$. Adapun rumus perhitungan Depreciation Index sebagai berikut:

$$
\text { AQI }=\frac{\left(\text { Depresi }_{(t-1)} /\left(\text { Depresi }_{(t-1)}+\text { Aktiva Tetap }_{(t-1)}\right)\right.}{\left(\text { Depresi }_{(t)} /\left(\text { Depresi }_{(t)}+\text { Aktiva Tetap }_{(t)}\right)\right.}
$$

f. $\quad$ Sales and General Administration Expenses Index (SGAI)

Sales and General Administration Expenses Index untuk membandingkan beban penjualan, umum, dan administrasi terhadap penjualan pada suatu tahun $(\mathrm{t})$ dan tahun sebelumnya ( $\mathrm{t}-1)$. Adapun rumus perhitungan Sales and General Administration Expenses Index sebagai berikut:

$$
\mathrm{SGAI}=\frac{\operatorname{SGAI}_{(\mathrm{t})} / \text { Penjualan }_{(\mathrm{t})}}{\mathrm{SGAI}_{(\mathrm{t}-1)} / \text { Penjualan }_{(\mathrm{t}-1)}}
$$

g. Leverage Index (LVGI)

Leverage Index untuk membandingkan jumlah hutang terhadap total aktiva pada suatu tahun $(\mathrm{t})$ dan tahun sebelumnya $(\mathrm{t}-1)$. Leverage Index bertujuan untuk mengetahui bagaimana tingkat hutang yang dimiliki perusahaan terhadap total aktivanya dari tahun ke tahun. 
Adapun rumus perhitungan Leverage Index sebagai berikut:

$$
\text { LVGI }=\frac{\text { Total Kewajiban }_{(\mathrm{t})} / \text { Total Aktiva }_{(\mathrm{t})}}{\text { Total Kewajiban }(\mathrm{t}-1) / \text { Total Aktiva }_{(\mathrm{t}-1)}}
$$

h. Total Accrual (TATA)

Total Accrual merupakan rasio untuk menjelaskan keuntungan akuntansi yang tidak diperoleh dari keuntungan kas. Perhitungannya adalah:

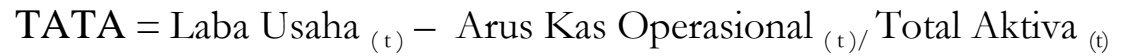

\subsection{Days Sales Receivable Index Terhadap Pendeteksian Fraud}

Pada laporan keuangan terdapat akun-akun tertentu yang besarnya saldo ditentukan oleh perusahaan berdasarkan suatu estimasi, misalnya akun piutang tak tertagih dan akun persediaan usang. Summers dan Sweeney (1998) mencatat bahwa akun piutang dan persediaan memerlukan penilaian subjektif dalam memperkirakan tidak tertagihnya piutang. Summers dan Sweeney, (1998) juga menyatakan bahwa manajer akan fokus terhadap kedua akun tersebut jika berniat melakukan manipulasi pada laporan keuangan. Berdasarkan uraian tersebut, diajukan hipotesis sebagai berikut :

$\mathbf{H}_{1}$. Days Sales Receivable Index berpengaruh positif terhadap Pendeteksian Fraud

2.5. Gross Margin Index Terhadap Pendeteksian Fraud

Gross Margin Index merupakan rasio yang mengukur tingkat profitabilitas perusahaan, yang mana rasio ini merepresentasikan prospek perusahaan di masa depan. Hal ini merepresentasikan prospek perusahaan yang mengalami penurunan. Kondisi perusahaan yang demikian dapat menjadi penyebab atas terjadinya kecurangan. Hal ini sebagaimana dinyatakan oleh Beneish (1999) bahwa adanya penurunan atas prospek perusahaan yang ditunjukkan jika Gross Margin Index $>1$ mengindikasikan terjadinya earning overstatement. Berdasarkan uraian tersebut, diajukan hipotesis sebagai berikut :

H2. Gross Margin Index berpengaruh positif terhadap Pendeteksian Fraud

2.6. Asset Quality Index Terhadap Pendeteksian Fraud

Menurut SAS No.99 (AICPA, 2002), financial target adalah risiko adanya tekanan berlebihan pada manajemen untuk mencapai target keuangan yang dipatok oleh direksi atau manajemen, termasuk tujuan-tujuan penerimaan insentif dari penjualan maupun keuntungan. Skousen et al., (2009) mengatakan bahwa Return on assets (ROA) yang sering digunakan dalam menilai kinerja manajer dan dalam menentukan bonus, kenaikan upah, dan lain-lain. Semakin tinggi Return on assets (ROA) yang ditargetkan perusahaan,maka semakin rentan manajemen akan melakukan manipulasi laba yang menjadi salah satu bentuk kecurangan sehingga memiliki hubungan positif dengan kecurangan laporan keuangan. Berdasarkan uraian tersebut, diajukan hipotesis sebagai berikut :

H. Asset Quality Index berpengaruh positif terhadap Pendeteksian Fraud

2.7. Sales Growth Index Terhadap Pendeteksian Fraud

Sesuai dengan SAS No. 99 manajer menghadapi tekanan (pressure) terkait financial statement fraud ketika financial stability dan/atau profitability terancam oleh ekonomi, industri ataupun kondisi operasi perusahaan. Loebbecke et al. (1989) and Bell et al. (1991) mengindikasikan bahwa dimana perusahaan mengalami pertumbuhan maka akan berada di bawah rata-rata industri sehingga manajer akan memanipulasi laporan. Persons (1995) menyarankan agar sales to accounts receivable, sales to total assets, and inventory to total sales dapat digunakan untuk mendeteksi fraud.

Berdasarkan uraian tersebut, diajukan hipotesis sebagai berikut :

H4. Sales Growth Index berpengaruh positif terhadap Pendeteksian Fraud 


\subsection{Depreciation Index Terhadap Pendeteksian Fraud}

Manajer menghadapi tekanan untuk melakukan financial statement fraud ketika stabilitas keuangan (financial stability) terancam oleh keadaan ekonomi, industri, dan situasi entitas yang beroperasi. Artinya dengan adanya ketidakstabilan keuangan, akan memicu terjadinya pelanggaran-pelanggaran yang dilakukan manajemen. Dari total aset dapat dilihat ukuran suatu perusahaan, dengan begitu manajer selalu berusaha untuk menampilkan laporan aset yang baik sepanjang tahunnya. Kondisi perusahaan yang tidak stabil dapat diakibatkan oleh kinerja manajemen yang tidak mampu memaksimalkan aset yang dimiliknya sehingga dapat menimbulkan perubahan aset yang terlalu terlalu tinggi atau bahkan terlalu rendah pada tahun tertentu. Jumlah aset perusahaan dimasa lalu yang kecil, dapat memotivasi perusahaan untuk meningkatkan total asetnya, hanya saja perusahaan yang memiliki aset kecil atau memiliki aset yang besar namun arus kas keluar juga besar, memiliki peluang untuk melakukan manipulasi agar stabilitas perusahaannya terlihat baik. Kondisi keuangan yang stabil dapat memperkecil risiko terjadinya kecurangan laporan keuangan. Kondisi tersebut dapat dilihat dari perubahan aset yang tidak terlalu signifikan berbeda dari tahun sebelumnya. Hal ini dapat menjadi tekanan bagi manajer untuk menampilkan kondisi perubahan aset yang stabil dan menunjukkan stabilitas perusahaan yang terlihat baik kepada para pengguna laporan keuangan, sebagai upaya menarik minat investor untuk menanamkan modal diperusahaannya. Berdasarkan uraian tersebut, diajukan hipotesis sebagai berikut:

H5. Depreciation Index berpengaruh positif terhadap Pendeteksian Fraud

2.9. Sales and General Administration Expenses Index Terhadap Pendeteksian Fraud

Manajer dari perusahaan yang melakukan kecurangan biasanya kurang bisa bersaing dibandingkan dengan manajer perusahaan yang tidak melakukan kecurangan dalam memanfaatkan aset perusahaan untuk menghasilkan pendapatan.Semakin besar nilai penjualan memberikan tekanan kepada pihak manajemen untuk lebih meningkatkan lagi penjualan di tahun berikutnya, sehingga menyebabkan semakin tingginya terjadi financial statement fraud yang dilakukan manajemen. Ketika suatu perusahaan tidak dapat mempertahankan aktivitas penjualannya maka perusahaan dapat melakukan fraud dengan cara memanfaatkan aset perusahaan untuk menghasilkan pendapatan. Arthur et.al (2010) mencatat ukuran investasi dalam piutang dagang tergantung pada tiga faktor : persentase penjualan kredit terhadap penjualan total, tingkat penjualan dan kebijakan kredit serta penagihan. Namun demikian, hanya variabel kebijakan kredit dan penagihan yang terbuka bagi manajer keuangan.Penilaian estimasi seperti persediaan yang sudah usang dan piutang tak tertagih memungkinkan manajemen untuk melakukan manipulasi, seperti memanipulasi umur ekonomis aset. Hal ini sesuai dengan pendapat Summers dan Sweeney (1998) dan Skousen et al (2008), akun persediaan dan piutang dapat digunakan untuk mengidentifikasi manipulasi laporan keuangan. Loebbecke et al., (1989) dan Skousen et al.(2008) mengamati sejumlah penipuan melibatkan piutang dan inventaris. Berdasarkan uraian tersebut, diajukan hipotesis sebagai berikut :

H6. Sales and General Administration Expenses Index berpengaruh positif terhadap Pendeteksian Fraud.

\subsection{Leverage Index Terhadap Pendeteksian Fraud}

Menurut Statement of Auditing Standards No. 99 (SAS No. 99), saat tekanan berlebihan dari pihak eksternal terjadi, maka terdapat risiko kecurangan terhadap laporan keuangan.Hal ini didukung oleh pendapat Skousen et. al. (2009) yang menyatakan bahwa salah satu tekanan yang sering kali dialami manajemen perusahaan adalah kebutuhan untuk mendapatkan tambahan utang atau sumber pembiayaan eksternal agar 
tetap kompetitif, termasuk pembiayaan riset dan pengeluaran pembangunan atau modal. Person (1999), leverage yang lebih besar dapat dikaitkan dengan kemungkinan yang lebih besar untuk melakukan pelanggaran terhadap perjanjian kredit dan kemampuan yang lebih rendah untuk memperoleh tambahan modal melalui pinjaman. Pernyataan tersebut juga diperkuat oleh Lou dan Wang (2009), ketika perusahaan mengalami tekanan eksternal perusahaan, dapat diidentifikasi risiko salah saji material yang lebih besar akibat kecurangan. Penelitian yang dilakukan oleh Skousen et al. (2009) menunjukkan bahwa persentase total hutang terhadap total aset berpengaruh positif terhadap financial statement fraud. Berdasarkan uraian tersebut, diajukan hipotesis sebagai berikut:

H7. Leverage Index berpengaruh terhadap Pendeteksian Fraud

\subsection{Total Accrual Terhadap Pendeteksian Fraud}

Perusahaan berusaha untuk menaikkan citra perusahaan agar lebih baik dengan cara memanipulasi laporan keuangannya. Bentuk manipulasi perusahaan pada laporan keuangan yang dilakukan oleh manajemen berhubungan dengan pertumbuhan aset perusahaan. (Skousen et al, 2009). Semakin tinggi total aset perusahaan berarti perusahaan tersebut mempunyai kekayaan yang tinggi. Berdasarkan uraian tersebut, diajukan hipotesis sebagai berikut:

H8. Total Accrual berpengaruh terhadap Pendeteksian Fraud

\section{METODE PENELITIAN}

\subsection{Pengukuran dan Definisi Operasional}

Dalam penelitian ini yang berperan sebagai variabel dependen adalah fraud. Variabel independen dalam penelitian ini adalah :

a. Day's Sales Receivable Index $\left(\mathrm{X}_{1}\right)$

Day's Sales Receivable Index yaitu rasio yang mempunyai tujuan untuk menemukan adanya selisih piutang yang dihasilkan dari kenaikan pendapatan.

b. Gross Margin Index $\left(\mathrm{X}_{2}\right)$

Gross Margin Index adalah suatu keadaan dimana margin perusahaan memburuk sehingga dapat mempengaruhi terjadinya manipulasi laba.

c. $\quad$ Asset Quality Index $\left(\mathrm{X}_{3}\right)$

Asset Quality Index merupakan rasio yang digunakan untuk menemukan selisih dalam aset lain yang dihasilkan dari kapitalisasi pengeluaran yang berlebihan

d. $\quad$ Sales Growth Index $\left(\mathrm{X}_{4}\right)$

Sales Growth Index merupakan rasio yang digunakan untuk mengelola persepsi pertumbuhan.

e. Depreciation Index $\left(\mathrm{X}_{5}\right)$

Depreciation Index adalah rasio untuk menghitung fasilitas fisik perusahaan untuk biaya satu periode.

f. $\quad$ Sales and General Administration Expenses Index $\left(\mathrm{X}_{6}\right)$

Sales and General Administration Expenses Index adalah penurunan administrasi dan pemasaran efisien (biaya Sales and General Administration Expenses Index lebih besar) yang dapat mempengaruhi perusahaan untuk melakukan manipulasi laba.

g. Leverage Index $\left(\mathrm{X}_{7}\right)$

Leverage Index merupakan rasio untuk menjelaskan pengaruh kendala utang dan pengaruh perusahaan untuk memanipulasi laba.

h. Total Accrual $\left(\mathrm{X}_{8}\right)$

Total Accrual merupakan rasio untuk menjelaskan keuntungan akuntansi yang tidak diperoleh dari keuntungan kas. 


\subsection{Metode Analisis Data}

Jenis penelitian ini menggunakan pendekatan kuantitatif, bertujuan untuk meneliti populasi atau sampel tertentu. Data yang dipakai pada penelitian ini adalah data sekunder berupa laporan keuangan (financial report) pada perusahaan BUMN yang berturut-turut terdaftar pada Bursa Efek Indonesia tahun 2012-2016. Populasi penelitian ini merupakan seluruh perusahaan BUMN yang terdaftar di Bursa Efek Indonesia (BEI) tahun 2012 - 2016. Pengambilan sampel dengan menggunakan purposive sampling dengan kriteria sebagai berikut:

1. Perusahaan BUMN yang terdaftar di BEI pada periode $2012-2016$

2. Perusahaan BUMN yang mempublikasikan laporan keuangan secara berturut-turut pada periode $2012-2016$.

3. Perusahaan BUMN yang memiliki laba positif pada periode $2012-2016$.

4. Perusahaan BUMN pada sektor perbankannya yang memiliki pendapatan selama periode $2012-2016$.

Sampel pada penelitian ini diperoleh dari perhitungan purposive sampling pada perusahaan BUMN tahun 2012-2016 sebagai berikut:

Tabel 1. Purposive Sampling

\begin{tabular}{|c|l|c|}
\hline No & \multicolumn{1}{|c|}{ Kriteria } & Jumlah \\
\hline 1. & Perusahaan BUMN yang terdaftar di BEI pada periode 2012-2016 & 20 \\
\hline 2. & $\begin{array}{l}\text { Perusahaan BUMN yang tidak mempublikasikan laporan keuangan } \\
\text { secara berturut-turut pada periode 2012-2016. }\end{array}$ & $(2)$ \\
\hline 3. & $\begin{array}{l}\text { Perusahaan BUMN yang tidak memiliki laba positif pada periode } \\
2012-2016 .\end{array}$ & $(4)$ \\
\hline 4. & $\begin{array}{l}\text { Perusahaan BUMN yang tidak memiliki pendapatan pada sektor } \\
\text { perbankannya selama periode 2012 - 2016 }\end{array}$ & Total sampel \\
\hline \multicolumn{2}{|c|}{ T) } \\
\hline
\end{tabular}

Penelitian ini menggunakan fraud sebagai variabel dependen, dan variabel independen terdiri dari delapan (8) variabel yaitu day's sales receivable index, gross margin index, asset quality index, sales growth index, depreciation index, sales and general administration expenses index, total accrual, leverage index

Pengujian dalam penelitian ini menggunakan analisis logistic regression, yaitu dengan melihat pengaruh day's sales receivable index, gross margin index, asset quality index, sales growth index, depreciation index, sales and general administration expenses index, leverage index, total accrual terhadap fraud. Analisis logistic regression dilakukan dengan menggunakan program Statistical Packagefor Sosial Sciens (SPSS).

Persamaan model logistic regression yang digunakan dalam penelitian ini adalah sebagai berikut:

$$
\begin{gathered}
F R A U D(\mathrm{Y})=\beta 0+\beta 1 \mathrm{DSRI}+\beta 2 \mathrm{GMI}+\beta 3 \mathrm{AQI}+\beta 4 \mathrm{SGI}+\beta 5 \mathrm{DEPI}+\beta 6 \mathrm{SGAI}+\beta 7 \\
\text { TATA }+\beta 8 \mathrm{LVGI}+\varepsilon \mathrm{i}
\end{gathered}
$$

\section{Keterangan :}

$\begin{array}{ll}\text { Fraud } & : \text { variabel dummy } \\ \beta 1, \beta 2, \beta 3, \beta 4, \beta 5, \beta 6, \beta 7, \beta 8 & : \text { Koefisien regresi } \\ \text { DSRI } & : \text { Day's sales receivables index } \\ \text { GMI } & : \text { Gross profit margin } \\ \text { AQI } & : \text { Asset quality index } \\ \text { SGI } & : \text { Sales growth index } \\ \text { DEPI } & : \text { Depreciation index } \\ \text { SGAI } & : \text { Sales and general administration expenses index } \\ \text { LVGI } & : \text { Leverage index }\end{array}$




$\begin{array}{ll}\text { TATA } & : \text { Total Assets } \\ \text { ci } & \text { : Residual }\end{array}$

Untuk menentukan apakah perusahaan terindikasi melakukan manipulasi ( $\mathrm{fraud}$ ) atau tidak, peneliti menggunakan model perhitungan Beneish M-Score. Jika Benesih M-Score lebih besar dari -2.22 mengindikasikan bahwa laporan keuangan telah dimanipulasi dan jika skor lebih kecil dari -2.22 maka perusahaan dikategorikan sebagai perusahaan yang tidak melakukan manipulasi (non fraud).

\section{HASIL ANALISIS DAN PEMBAHASAN}

\subsection{Hasil Analisis}

\subsubsection{Statistik Deskriptif}

Statistik Deskriptif adalah metode-metode yang berkaitan dengan pengumpulan dan penyajian suatu gugus data sehingga memberikan informasi yang berguna. Informasi yang dapat diperoleh dari statistika deskriptif antara lain ukuran pemusatan data, ukuran penyebaran data serta kecenderungan suatu gugus data. Hasil pengolahan data dapat dilihat dari tabel statistik deskriptif di bawah ini :

\section{Tabel 2. Statistik Deskriptif}

\section{Descriptive Statistics}

\begin{tabular}{|c|c|c|c|c|c|}
\hline & $\mathrm{N}$ & Minimum & Maximum & Mean & Std. Deviation \\
\hline DSRI & 50 & .034 & 70.642 & 2.34400 & 9.923884 \\
\hline GMI & 47 & .250 & 13.723 & 1.73611 & 2.512004 \\
\hline AQI & 50 & .287 & 1004.423 & 86.77750 & 262.698025 \\
\hline SGI & 50 & .008 & 9.249 & 1.78994 & 2.360440 \\
\hline DEPI & 46 & .111 & 1.611 & .97911 & .318986 \\
\hline SGAI & 50 & .0930 & 12.1890 & 1.799080 & 2.5020173 \\
\hline LVGI & 50 & .095 & 16.712 & 1.67066 & 2.684147 \\
\hline TATA & 42 & .010 & 5.031 & .34986 & .770457 \\
\hline Valid N (listwise) & 34 & & & & \\
\hline
\end{tabular}

Sumber : Pengolahan data, 2018

Pada tabel 2 di atas, dapat dilihat bahwa nilai minimum variabel DSRI adalah 0,034 nilai maksimum adalah 70,642 dan nilai mean adalah 2,3440, standar deviasi variabel adalah 9,923884. Untuk variabel GMI, nilai minimumnya adalah 0,250 , nilai maksimum adalah 13,723 dan nilai mean adalah 1,73611 dan standar deviasi adalah 2,512004. Untuk variabel AQI, nilai minimumnya adalah 0,287 , nilai maksimum adalah 1004,423 dan nilai mean adalah 85,77750 dan standar deviasi adalah 262,698025.

Untuk variabel SGI, nilai minimumnya adalah 0,008, nilai maksimum adalah 9,249 dan nilai mean adalah 1,78994 dan standar deviasi adalah 2,360440. Untuk variabel DEPI, nilai minimumnya adalah 0,111 , nilai maksimum adalah 1,611 dan nilai mean adalah 0,97911 dan standar deviasi adalah 0,318986. Untuk variabel SGAI, nilai minimumnya adalah 0,930, nilai maksimum adalah 12,1890 dan nilai mean adalah 1,799080 dan standar deviasi adalah 2,5020173. Untuk variabel LVGI, nilai minimumnya adalah 0,095 , nilai maksimum adalah 16,712 dan nilai mean adalah 1,67066 dan standar deviasi adalah 2,684147. Untuk variabel TATA, nilai minimumnya adalah 0,010 , nilai maksimum adalah 5,031 dan nilai mean adalah 0,34986 dan standar deviasi adalah 0,770457. 


\subsubsection{Menguji Model Fit (Overall Model Fit Test)}

Uji regresi logistik yang pertama dilakukan dalam penelitian ini adalah menguji apakah model regresi yang dibuat adalah model fit dengan data penelitian. Pengujian ini dilakukan dengan melihat nilai -2 LL awal dengan -2 LL akhir pada tabel iteration history pada hasil penelitian. Tabel di bawah akan menunjukkan hasil dari -2 log likelihood awal pada block number $=0$, adalah sebagai berikut :

Tabel 3. Nilai -2 log likelihood (-2 LL Awal) Iteration History ${ }^{\text {a,b,c }}$

\begin{tabular}{c|c|r|rr}
\hline \multirow{2}{*}{ Iteration } & & \multicolumn{2}{c}{ Coefficients } \\
\cline { 3 - 5 } Step 0 & 1 & -2 Log likelihood & Constant & -.919 \\
\cline { 3 - 5 } & 2 & 43.222 & -.992 \\
\cline { 2 - 5 } & 3 & 43.181 & -.993 \\
\cline { 2 - 5 } & 4 & 43.181 & -.993 \\
\hline
\end{tabular}

Sumber : Pengolahan data, 2018

Tabel 4. Nilai -2 log likelihood (-2 LL Akhir)

Iteration History ${ }^{\mathrm{a}, \mathrm{b}, \mathrm{c}, \mathrm{d}}$

$-2 \log$

Iteration likelihood Constant DSRI

Coefficients

\begin{tabular}{|c|c|c|c|c|c|c|c|c|c|c|c|}
\hline Step & 1 & 32.127 & -1.458 & -.005 & -.188 & .001 & .593 & -.418 & .224 & .091 & -.380 \\
\hline \multirow[t]{19}{*}{1} & 2 & 30.134 & -1.946 & -.010 & -.271 & -.001 & 1.046 & -.675 & .286 & .146 & -.593 \\
\hline & 3 & 29.400 & -2.726 & -.012 & -.269 & -.005 & 1.703 & -.662 & .292 & .176 & -.669 \\
\hline & 4 & 29.274 & -3.110 & -.015 & -.251 & -.007 & 2.081 & -.681 & .288 & .185 & -.699 \\
\hline & 5 & 29.259 & -3.198 & -.018 & -.245 & -.006 & 2.178 & -.693 & 287 & .186 & -.707 \\
\hline & 6 & 29.251 & -3.204 & -.019 & -.244 & -.004 & 2.183 & -.694 & .287 & .187 & -.708 \\
\hline & 7 & 29.231 & -3.211 & -.019 & -.244 & .003 & 2.183 & -.694 & .287 & .187 & -.708 \\
\hline & 8 & 16.548 & -9.134 & -.050 & -.191 & 6.708 & 2.120 & -.556 & .188 & .271 & -.937 \\
\hline & 9 & 8.775 & -17.515 & -.090 & -.328 & 15.340 & 1.693 & -.116 & .221 & .463 & -1.296 \\
\hline & 10 & 4.848 & -26.979 & -.140 & -.637 & 25.616 & .872 & .132 & .297 & .687 & -1.697 \\
\hline & 11 & 2.437 & -39.716 & -.202 & -1.275 & 39.998 & .204 & -.237 & .352 & 1.005 & -2.372 \\
\hline & 12 & .962 & -54.726 & -.235 & -3.309 & 58.704 & -.716 & -1.220 & .388 & 1.447 & -3.396 \\
\hline & 13 & .358 & -69.713 & -.306 & -5.891 & 77.623 & -1.572 & -2.173 & .452 & 1.925 & -4.510 \\
\hline & 14 & .134 & -85.941 & -.375 & -8.151 & 97.183 & -2.341 & -2.921 & .486 & 2.419 & -5.619 \\
\hline & 15 & .050 & -103.065 & -.444 & -10.233 & 117.278 & -3.077 & -3.502 & .503 & 2.923 & -6.720 \\
\hline & 16 & .018 & -120.737 & -.513 & -12.218 & 137.724 & -3.800 & -3.990 & .512 & 3.435 & -7.819 \\
\hline & 17 & .007 & -138.699 & -.583 & -14.154 & 158.377 & -4.516 & -4.446 & .519 & 3.951 & -8.919 \\
\hline & 18 & .003 & -156.830 & -.652 & -16.063 & 179.166 & -5.229 & -4.896 & .526 & 4.469 & -10.023 \\
\hline & 19 & .001 & -175.085 & -.721 & -17.950 & 200.062 & -5.940 & -5.349 & .532 & 4.989 & -11.132 \\
\hline & 20 & .000 & -193.443 & -.790 & -19.817 & 221.049 & -6.651 & -5.805 & .539 & 5.511 & -12.243 \\
\hline
\end{tabular}

Sumber : Pengolahan data, 2018

Pada tabel 3 di atas dapat dilihat bahwa nilai -2 log likelihood awal (-2 LL awal) pada block number $=0$, yaitu yang hanya memasukkan konstanta saja adalah 43,181 dan pada tabel 4 -2 log likelihood akhir (-2LL akhir) pada block number $=1$ yang memasukkan konstanta dan seluruh variabel independen adalah sebesar 0,000. Adanya pengurangan nilai antara -2LL awal dengan -2LL akhir menunjukkan bahwa model fit dengan data. Menurut Ghozali (2013), terjadinya penurunan nilai -2 log likelihood akan menunjukkan bahwa model penelitian ini dinyatakan model fit yang artinya penurunan likelihood ini menunjukkan model 
regresi yang lebih baik atau dengan kata lain model yang dihipotesiskan model fit dengan data.

\subsubsection{Uji Koefisien Determinasi (Nagelkerke R Square)}

Nilai Nagelkerke $R$ Square bervariasi antara 1(satu) dan 0 (nol). Semakin mendekati nilai 1 maka model dianggap semakin goodness of fit sementara semakin mendekati 0 maka model semakin tidak goodness of fit. Untuk lebih jelasnya dapat dilihat pada tabel 5 sebagai berikut :

\begin{tabular}{cr|r|r}
\multicolumn{6}{c}{ Tabel 5. Model Summary } \\
Step & -2 Log likelihood & Cox \& Snell R Square & \multicolumn{2}{c}{ Nagelkerke R Square } \\
\hline 1 & $.000^{\mathrm{a}}$ & .343 & 1.000 \\
\hline
\end{tabular}

Sumber : Pengolahan data, 2018

Berdasarkan tabel 5 di atas, maka dapat dilihat bahwa hasil nilai nagelkerke $R$ Square pada penelitian ini sebesar 1,000, yang dapat menyatakan bahwa variabilitas variabel dependen yang dapat dijelaskan oleh variabilitas variabel independen sebesar 1,0\%, sedangkan sisanya sebesar $99 \%$ dapat dijelaskan oleh faktor-faktor lain yang tidak disertakan dalam penelitian ini.

\subsubsection{Uji Kelayakan Model}

Untuk menilai kelayakan model regresi yang digunakan dapat dilihat dari nilai Hosmer and Lemeshow test, seperti yang disajikan pada tabel di bawah ini :

Tabel 6. Uji Kelayakan Model

Hosmer and Lemeshow Test

\begin{tabular}{|c|c|c|c|}
\hline Step & Chi-square & df & Sig. \\
\hline 1 & .000 & 7 & 1.000 \\
\hline
\end{tabular}

Sumber : Pengolahan data, 2018

Pada tabel uji Hosmer and Lemeshow test di atas menunjukkan bahwa besarnya nilai chi-square 0,000 dan probabilitas signifikansi 1,000 yang nilai berada di atas 0,05 sehingga dapat disimpulkan bahwa model regresi logistik biner yang digunakan mampu memprediksi nilai observasinya.

\subsubsection{Pengujian Hipotesis}

Hasil pengujian hipotesis bertujuan untuk mengetahui pengaruh day's sales receivable index, gross margin index, asset quality index, sales growth index, depreciation index, sales and general administration expenses index, total accrual, leverage index terhadap fraud pada perusahaan BUMN yang terdaftar di Bursa Efek Indonesia periode 2012-2016. Informasi awal untuk pengujian dengan regresi logistik ditunjukkan dalam tabel-tabel di bawah ini.

\subsubsection{Uji Simultan - G}

Tabel 7. Uji Simultan - G

Omnibus Tests of Model Coefficients

\begin{tabular}{ccc|c|c} 
& & Chi-square & df & Sig. \\
\hline \multirow{3}{*}{ Step 1 } & Step & 43.181 & 8 & .000 \\
\cline { 2 - 5 } & Block & 43.181 & 8 & .000 \\
\cline { 2 - 4 } & Model & 43.181 & 8 & .000 \\
\hline
\end{tabular}

Sumber : Pengolahan data, 2018

Pada hasil uji simultan (Omnibus Test of Model Coefficient) yang dilakukan dengan program statistika SPSS diperoleh nilai sig sebesar $0,000<$ alpha 0,05 . Sehingga dapat disimpulkan bahwa seluruh variabel independen (day's sales receivable index, gross margin 
index, asset quality index, sales growth index, depreciation index, sales and general administration expenses index, total accrual, leverage index) dalam penelitian ini secara simultan berpengaruh terhadap variabel dependen (fraud).

\subsubsection{Uji Parsial - Wald dan Uji Hipotesis Logistik}

Untuk menentukan hasil akhir dari penelitian dan menjawab hipotesis yang disusun sebelumnya, digunakan tabel variables in the equation yang ada pada output hasil pengolahan data dapat disajikan sebagai berikut:

\section{Tabel 8. Uji Parsial - Wald dan Uji Hipotesis Logistik \\ Variables in the Equation}

\begin{tabular}{|c|c|c|c|c|c|c|c|}
\hline & & B & S.E. & Wald & $\mathrm{df}$ & Sig. & $\operatorname{Exp}(B)$ \\
\hline \multirow[t]{9}{*}{ Step $1^{\mathrm{a}}$} & DSRI & -.790 & 38.412 & .000 & 1 & .984 & .454 \\
\hline & GMI & -19.817 & 812.890 & .001 & 1 & .981 & .000 \\
\hline & AQI & 221.049 & 2290.836 & .009 & 1 & .923 & $1.001 \mathrm{E}+96$ \\
\hline & SGI & -6.651 & 231.752 & .001 & 1 & .977 & .001 \\
\hline & DEPI & -5.805 & 641.941 & .000 & 1 & .993 & .003 \\
\hline & SGAI & .539 & 131.280 & .000 & 1 & .997 & 1.714 \\
\hline & LVGI & 5.511 & 46.771 & .014 & 1 & .906 & 247.392 \\
\hline & TATA & -12.243 & 168.627 & .005 & 1 & .942 & .000 \\
\hline & Constant & -193.443 & 2925.023 & .004 & 1 & .947 & .000 \\
\hline
\end{tabular}

a. Variable(s) entered on step 1: DSRI, GMI, AQI, SGI, DEPI, SGAI, LVGI, TATA. Sumber : Pengolahan data, 2018

Tabel 8 di atas memperlihatkan hasil pengujian hipotesis regresi logistik pada tingkat signifikansi 5\% atau 0,05. Dari hasil pengujian tersebut pada kolom B maka diperoleh model persamaan regresi logistik sebagai berikut :

$$
\begin{aligned}
\operatorname{Ln} \frac{\mathrm{FR}}{1-\mathrm{FR}}= & -194,443-0,790 \mathrm{DSRI}-19,817 \mathrm{GMI}+221,049 \mathrm{AQI}-6,651 \mathrm{SGI} \\
& -5,805 \mathrm{DEPI}+0,539 \mathrm{SGAI}+5,511 \mathrm{LVGI}-12,243 \mathrm{TATA}
\end{aligned}
$$

Interpretasi dari persamaan regresi logistik di atas adalah sebagai berikut :

1. Dengan nilai intersep yang sebesar -193.443 berarti probabilitas perusahaan untuk tidak bisa melakukan kecurangan.

2. Variabel day's sales receivable index menunjukkan nilai koefisien variabel sebesar 0,790 dengan probabilitas variabel sebesar 0,984 di atas tingkat signifikansi 0,05 (5 persen). Berdasarkan nilai koefisien variabel dan nilai signifikansi tersebut maka day's sales receivable index berpengaruh negatif dan tidak signifikan terhadap fraud. Dengan demikian hipotesis pertama dinyatakan ditolak.

3. Variabel gross margin index menunjukkan nilai koefisien variabel sebesar - 19,817 dengan probabilitas variabel sebesar 0,981 di atas tingkat signifikansi 0,05 (5 persen). Berdasarkan nilai koefisien variabel dan nilai signifikansi tersebut maka gross margin index berpengaruh negatif dan tidak signifikan terhadap fraud Dengan demikian hipotesis kedua dinyatakan ditolak.

4. Variabel asset quality index menunjukkan nilai koefisien variabel sebesar 221,049 dengan probabilitas variabel sebesar 0,923 di atas tingkat signifikansi 0,05 (5 persen). Berdasarkan nilai koefisien variabel dan nilai signifikansi tersebut maka asset quality index berpengaruh positif dan tidak signifikan terhadap fraud. Dengan demikian hipotesis ketiga dinyatakan ditolak.

5. Variabel sales growth index menunjukkan nilai koefisien variabel sebesar $-6,651$ dengan probabilitas variabel sebesar 0,977 di atas tingkat signifikansi 0,05 (5 persen). 
Berdasarkan nilai koefisien variabel dan nilai signifikansi tersebut maka sales growth index berpengaruh negatif dan tidak signifikan terhadap fraud. Dengan demikian hipotesis empat dinyatakan ditolak.

6. Variabel depreciation index menunjukkan nilai koefisien variabel sebesar - 5,805 dengan probabilitas variabel sebesar 0,993 di atas tingkat signifikansi 0,05 (5 persen). Berdasarkan nilai koefisien variabel dan nilai signifikansi tersebut maka sales growth index berpengaruh negatif dan tidak signifikan terhadap fraud. Dengan demikian hipotesis kelima dinyatakan ditolak.

7. Variabel sales and general administration expenses index menunjukkan nilai koefisien variabel sebesar 0,539 dengan probabilitas variabel sebesar 0,997 di atas tingkat signifikansi 0,05 (5 persen). Berdasarkan nilai koefisien variabel dan nilai signifikansi tersebut maka sales and general administration expenses index berpengaruh positif dan tidak signifikan terhadap fraud. Dengan demikian hipotesis keenam dinyatakan ditolak.

8. Variabel leverage index menunjukkan nilai koefisien variabel sebesar 5,511 dengan probabilitas variabel sebesar 0,906 di atas tingkat signifikansi 0,05 (5 persen). Berdasarkan nilai koefisien variabel dan nilai signifikansi tersebut maka leverage index berpengaruh positif dan tidak signifikan terhadap fraud. Dengan demikian hipotesis ketujuh dinyatakan ditolak.

9. Variabel total accrual menunjukkan nilai koefisien variabel sebesar - 12,243 dengan probabilitas variabel sebesar $0,942 \mathrm{di}$ atas tingkat signifikansi 0,05 (5 persen). Berdasarkan nilai koefisien variabel dan nilai signifikansi tersebut maka total accrual berpengaruh negatif dan tidak signifikan terhadap fraud. Dengan demikian hipotesis ke delapan dinyatakan ditolak.

\subsection{Pembahasan}

\subsubsection{Pengaruh Days Sales Receivable Index Terhadap Pendeteksian Fraud}

Berdasarkan hasil analisis regresi logistik, menunujukkan bahwa variabel Days Sales Receivable Index (DSRI) menghasilkan nilai koefisien regresi (B) sebesar 37,407 dan tingkat signifikansi sebesar 0,999 lebih besar dari 0,05. Sehingga, dapat diartikan bahwa tidak adanya pengaruh variabel DSRI terhadap pendeteksian fraud. Hal ini tidak sejalan dengan Summers dan Sweeney, (1998) yang menyatakan bahwa manajer akan fokus terhadap kedua akun tersebut jika berniat melakukan manipulasi pada laporan keuangan.

\subsubsection{Pengaruh Gross Margin Index Terhadap Pendeteksian Fraud}

Berdasarkan hasil analisis regresi logistik, menunujukkan bahwa variabel gross margin index menunjukkan nilai koefisien variabel sebesar - 19,817 dengan probabilitas variabel sebesar 0,981 di atas tingkat signifikansi 0,05 (5 persen). Hal ini merepresentasikan prospek perusahaan yang mengalami penurunan. Kondisi perusahaan yang demikian dapat menjadi penyebab atas terjadinya kecurangan. Hal ini sejalan yang dinyatakan oleh Beneish (1999) bahwa adanya penurunan atas prospek perusahaan (yang ditunjukkan jika GMI >1) mengindikasikan terjadinya earning overstatement.

\subsubsection{Pengaruh Asset Quality Index Terhadap Pendeteksian Fraud}

Berdasarkan hasil analisis regresi logistik, menunujukkan bahwa variabel asset quality index menghasilkan nilai koefisien regresi (B) sebesar 221,049 dan tingkat signifikansi sebesar 0,923 lebih besar dari 0,05. Maka dapat disimpulkan bahwa asset quality index tidak berpengaruh signifikan terhadap financial statement fraud. Artinya bahwa besar kecilnya tingkat Asset Quality Index yang ditargetkan perusahaan tidak mempengaruhi manajemen untuk melakukan kecurangan laporan keuangan.

Hasil penelitian ini berbeda dengan temuan Skousen et al. (2009) yang menyimpulkan bahwa asset quality index berpengaruh positif terhadap financial statement fraud. Tidak 
berpengaruhnya asset quality index terhadap financial statement fraud pada penelitian ini kemungkinan disebabkan karena manajer menganggap bahwa besarnya target Asset Quality Index perusahaan masih dinilai wajar dan bisa dicapai. Manajer tidak menganggap bahwa target asset quality index tersebut sebagai target keuangan yang sulit untuk dicapai sehingga besarnya target asset quality index tidak memicu terjadinya kecurangan laporan keuangan yang dilakukan oleh manajemen.

\subsubsection{Pengaruh Sales Growth Index Terhadap Pendeteksian Fraud}

Berdasarkan hasil analisis regresi logistik, menunujukkan bahwa variabel sales growh index menghasilkan nilai koefisien regresi (B) sebesar - 6,651 dan tingkat signifikansi 0,977 lebih besar dari 0,05. Maka dapat disimpulkan bahwa sales grow index tidak memberikan pengaruh terhadap pendeteksian fraud. Disebabkan karena adanya tidak adanya tekanan dan tuntutan yang dirasakan oleh manajer dalam menumbuhkan penjualan. Sehingga, para manajer berupaya untuk sebaik mungkin memberikan yang terbaik bagi perusahaan dengan berbagai cara. Hal ini tidak sejalan dengan penelitian yang dilakukan oleh Loebbecke et al. (1989) and Bell et al. (1991) mengindikasikan bahwa dimana perusahaan mengalami pertumbuhan maka akan berada di bawah ratarata industri sehingga manajer akan memanipulasi laporan.

\subsubsection{Pengaruh Depreciation Index Terhadap Pendeteksian Fraud}

Berdasarkan hasil analisis regresi logistik, menunujukkan bahwa variabel depreciation index menunjukkan nilai koefisien variabel sebesar - 5,805 dengan probabilitas variabel sebesar 0,993 di atas tingkat signifikansi 0,05 (5 persen). Depreciation Index tidak memberikan pengaruh terhadap pendeteksian fraud. Hal ini disebabkan oleh suatu kebijakan penyusutan yang diterapkan dan dilakukan oleh perusahaan telah sesuai dengan kebijakan yang berlaku.

\subsubsection{Pengaruh Sales and General Administration Expenses Index Terhadap} Pendeteksian Fraud

Berdasarkan hasil analisis regresi logistik, menunujukkan bahwa variabel sales and general administration expenses index menghasilkan nilai koefisien regresi (B) sebesar 0,539 dengan probabilitas variabel sebesar 0,997 di atas tingkat signifikansi 0,05 (5 persen). Sales and General Administration Expenses Index tidak memberikan pengaruh terhadap pendeteksian fraud. Hal ini dikarenakan ketika suatu perusahaan dapat mempertahankan aktivitas penjualannya maka perusahaan tidak dapat melakukan fraud dengan cara memanfaatkan aset perusahaan untuk menghasilkan pendapatan. Hal ini tidak sesuai dengan pendapat Summers dan Sweeney (1998, dalam Skousen et al., 2008) akun persediaan dan piutang dapat digunakan untuk mengidentifikasi manipulasi laporan keuangan.

\subsubsection{Pengaruh Leverage Index Terhadap Pendeteksian Fraud}

Berdasarkan hasil analisis regresi logistik, menunujukkan bahwa variabel leverage index menghasilkan nilai koefisien regresi (B) sebesar 5,511 dan tingkat signifikansi sebesar 0,906 lebih besar dari 0,05. Leverage Index tidak memberikan pengaruh terhadap pendeteksian fraud. Hal ini dikarenakan besar kecilnya rasio perubahan dalam piutang usaha tidak memicu manajemen untuk melakukan kecurangan laporan keuangan. Hasil penelitian ini sejalan dengan pendapat Person (1999) yang menyatakan bahwa leverage yang lebih besar dapat dikaitkan dengan kemungkinan yang lebih besar untuk melakukan pelanggaran terhadap perjanjian kredit dan kemampuan yang lebih rendah untuk memperoleh tambahan modal melalui pinjaman.

\subsubsection{Pengaruh Total Accrual Terhadap Pendeteksian Fraud}

Berdasarkan hasil analisis regresi logistik, menunujukkan bahwa variabel total accrual menunjukkan nilai koefisien variabel sebesar - 12,243 dengan probabilitas variabel sebesar 0,942 di atas tingkat signifikansi 0,05 (5 persen). Total Accrual to Total Asset 
memberikan pengaruh terhadap pendeteksian fraud. Hal ini karena Apabila dalam total akrual menunjukkan kerugian akibat penerimaan lebih kecil dari pengeluaran, maka terdapat indikasi pengeluaran yang fiktif atau tidak menunjukkan angka sebenarnya. Hal ini tidak sejalan dengan penelitian yang dilakukan oleh Skousen et al, 2009 yang menyatakan bahwa bentuk manipulasi perusahaan pada laporan keuangan yang dilakukan oleh manajamen berhubungan dengan pertumbuhan aset perusahaan. Semakin rendah total aset perusahaan berarti perusahaan tersebut mempunyai kekayaan yang kecil.

\section{KESIMPULAN DAN SARAN}

\subsection{Kesimpulan}

Berdasarkan pengujian terhadap 8 (delapan) hipotesis yang dilakukan dengan menggunakan analisis regresi logistik, disimpulkan sebagai berikut :

Days Sales Receivable Index, Gross Margin Index, Asset Quality Index, Sales Growth Index, Depreciation Index, Sales and General Administration Expenses Index, Leverage Index, dan Total Accrual tidak berpengaruh signifikan terhadap kecurangan laporan keuangan. Artinya keempat variabel tersebut tidak mampu mendeteksi potensi kecurangan yang terjadi dalam perusahaan BUMN.

\subsection{Saran}

Dalam penelitian ini terdapat beberapa keterbatasan yang kemungkinan dapat mempengaruhi hasil penelitian, antara lain variabel yang digunakan untuk mendeteksi financial statement fraud pada penelitian ini hanya sebatas variabel yang dikembangkan dari Beneish M-Score Model dan disarankan untuk menambahkan model yang lainnya untuk dapat mendeteksi terjadinya financial statement fraud, misalnya manajemen laba, perataan laba dan model Altman serta studi selanjutnya dapat dilakukan dengan memperluas sampel yang mencakup laporan keuangan perusahaan yang belum atau tidak dinyatakan melakukan kecurangan, guna membuktikan sejauh mana dua model (Beneish M-Score Model dan Altman) tersebut dapat digunakan secara efektif untuk memprediksi terjadinya kecurangan keuangan dalam perusahaan.

\section{DAFTAR PUSTAKA}

Arthur, J. Keown dan John, D Martin. (2010). Manajemen Keuangan: Prinsip dan Penerapan Jilid 2. Jakarta : Indeks.

Albrecht,W. S., Albrecht, C.O., Albrecht , C.C.and Zimbelman, Mark F.(2011).Fraud Examination 4th Edition.Cengage Learning: Mason, Ohio USA.

Bell, T., S. Szykowny, and J. Willingham. (1993). Assessing the Likelihood of Fraudulent Financial Reporting: A Cascaded Logic Approach. Working Paper, KPMG Peat Marwick. Montvale N.J.

Beneish, Messod Daniel and Lee, Charles M.C. and Nichols, D. Craig, Fraud Detection and Expected Returns (February 2, 2012). Available at SSRN: https://ssrn.com/abstract=1998387 or http://dx.doi.org/10.2139/ssrn.1998387.

Christy,I.M.,Sugito, dan Abdul Hoyyi. (2015). Penerapan Formula Beneish M-Score dan Analisis Diskriminan Linier untuk Klasifikasi Perusahaan Manipulator dan Non Manipulator, Studi Kasus di Bursa Efek IndonesiaTahun 2013.Jurnal Gaussian.Vol. 4, No. 2, Tahun 2015.

Cressey, D.R. (1953). Other People's Money: A Study in the Social Psychology of Embezzlement . New York, NY: The Free Press.

Darmawan, Astrid Z. (2016). Analisis Beneish Ratio Index untuk Mendeteksi Kecurangan Laporan Keuangan. Jurnal Profita.Edisi 6 Tahun 2016. 
Fahmi, Irham. (2012). Analisis Laporan Keuangan.Cetakan Ke-2. Bandung: Alfabeta

Hariri, Ayub Wijayanti, dan Srilucki W.. (2013). Predicitng Financial Statements Corporate Fraud: Beneish M-Score Model. International Journal of Trade, Economics and Financial. Vol. 5, No. 2, April.

Hermansyah, Wawan. (2015). Tax Fraud. Tesis. Surabaya: Universitas Airlangga.

Hakim, Ifsan Lukmanul. 22 Juli 2015. Skandal Terungkap, CEO Toshiba Mundur. Liputan6, (online), (Skandal Terungkap, CEO Toshiba Mundur - Bisnis Liputan6.com.htm, diunduh 8 April 2017).

Priantara, Diaz. (2013). Fraud Auditing \& Investigation. Jakarta: Mitra Wacana Media.

Person, Obeua. (1999). "Using Financial Information to Differentiate Failed vs Surviving Finance Companies in Thailand: An Implication For Emerging Economies. Multinational Finance Journal. Vol. 3. No.2. pp.127-145.

Kasmir. (2016). Analisis Laporan Keuangan. Jakarta: Raja Grafindo Persada.

Lou, Y.I., \& Wang, M.L. (2009).Fraud Risk Factor of the Fraud Triangle Assesing the Likelihood of Fraudulent Financial Reporting. Journal of Business and Economic Research. Vol.7 (2), 62-66.

Loebbecke, J., M. Eining. and J. Willingham. (1989). Auditor's Experience with Material Irregularities: Frequency, Nature, and Detectability. Auditing: A Journal of Practice \& Theory. Fall:1-28.

Lev, Baruch \& S. Ramu Thiagarajan. (1993). Fundamental Information Analysis. Journal of Accounting Research, Vol. 31, No. 2 (Autumn, 1993), pp. 190-215.

Skousen, J.C., Wright, J.C., Smith Kevin, R. (2009), "Detecting and Predicting Financial Statement Fraud: The Effectiveness of The Fraud Triangle and SAS No. 99." Advances in Financial Economics, Vol. 13 No.1: 53-81.

Sukanto, Eman. (2009). Perbandingan Persepsi Auditor Internal, Akuntan Publik, Dan Auditor Pemerintah Terhadap Penugasan Fraud Audit Dan Profil Fraud Auditor. Fokus Ekonomi: Vol. 4 No. 1 Juni 2009.

Summers, S., \& Sweeney, J. (1998). "Fraudulently Misstated Financial Statements and Insider Trading: An Empirical Analysis". The Accounting Review. Volume 73 No.1.

Tuanakotta, Theodorus M. (2010). Akuntansi Forensik dan Audit Investigatif, Edisi 2. Jakarta: Salemba 4. 